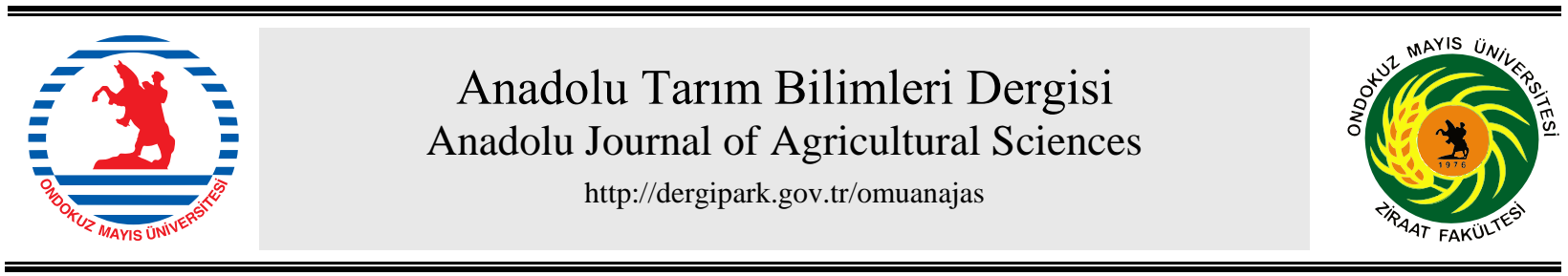

Araştırma/Research

Anadolu Tarım Bilim. Derg./Anadolu J Agr Sci, 36 (2021)

ISSN: 1308-8750 (Print) 1308-8769 (Online)

doi: 10.7161/omuanajas.805765

\title{
Maş Fasulyesi Genotiplerinde Farklı Ekim Derinliklerinin Çimlenme ve Bazı Büyüme Parametreleri Üzerine Etkisi
}

\author{
Cengiz Türkay ${ }^{\mathrm{a}}$, (1) Ruziye Karaman ${ }^{\mathrm{a}^{*}}$ \\ ${ }^{a}$ Isparta Uygulamalı Bilimler Üniversitesi, Ziraat Fakültesi, Tarla Bitkileri Bölümü, Isparta, Türkiye
}

*Sorumlu yazar/corresponding author: ruziyekaraman@isparta.edu.tr

Geliş/Received 05/10/2020 Kabul/Accepted 11/11/2020

\begin{abstract}
ÖZET
Araştırma, Isparta Uygulamalı Bilimler Üniversitesi Ziraat Fakültesi uygulama alanlarında 2020 yılında açık alanda saksı denemesi şeklinde (16 Haziran - 24 Temmuz) yürütülmüştür. Çalışmada büyük tohuma sahip Partow çeşidi, orta büyüklüğe sahip 70 E 07 ve küçük tohuma sahip 70 S 07 genotipleri materyal olarak kullanılmıştır. Maş fasulyeleri 2, 4 ve $6 \mathrm{~cm}$ derinliğinde, her saksıda 25 adet tohum olacak şekilde ekim yapılmıştır. Saksı toprağı; tarla toprağı ve torf karışımından oluşmuş ve deneme tesadüf parsellerinde deneme deseninde 3 tekerrürlü olarak yürütülmüştür. Çalışmada çimlenme (çimlenme oranı, çimlenme indeksi, ortalama çimlenme süresi) ve fide (fide ve kök uzunluğu, toprak üstü kuru ağırlık, kök kuru ağırlığı, toprak üstü kuru ağırlığı / toplam kuru ağırlığı oranı) özellikleri incelenmiştir. Elde edilen sonuçlara göre, çimlenme oranı ve indeksi, kök uzunluğu ile toprak üstü kuru ağırlık/toplam kuru ağırlık oranı (orta), kök kuru ağırlığı ve toprak üstü kuru ağırlık (küçük) özelliklerinde orta ve küçük tohumlar, ortalama çimlenme süresi ile fide uzunluğu bakımından büyük tohumlar ön plana çıkmıştır. Ekim derinliği yönünden çimlenme ve fide özellikleri incelendiğinde, 2 ve $4 \mathrm{~cm}$ 'ye yapılan ekimlerden en yüksek değerler elde edilmiştir. Sonuç olarak, çalışmada farklı tane büyüklüğüne sahip maş fasulyesi tohumlarının çimlenme ve fide özelliklerinin ekim derinliklerinden etkilendiği belirlenmiştir. Maş fasulyesi yetiştiriciliğinde farklı büyüklükteki tohumlar 2-4 cm derinliğe ekildiğinde oluşacak bitkilerin çimlenme ile fide gelişim özellikleri yönünden daha iyi performans gösterdiği saptanmıştır.
\end{abstract}

Effect of sowing depth on germination and some growth parameters in mung bean genotypes different seed size

\section{ABSTRACT}

The research was carried out as a pot in an open field (June 16 - July 24) at Isparta University of Applied Sciences, Faculty of Agriculture experiments area in 2020. In the study, Partow variety as a large seed, 70 E 07 genotype as a medium size and 70 S 07 genotype as a small seed were used as seed material. According to the seed sizes (large, medium and small), the mung beans were planted in 2, 4 and $6 \mathrm{~cm}$ depths with 25 seeds in each pot. It is consisted of potting soil, field soil and peat (3:1) and the research was established to completely randomized plot design with three replications. In the study, germination (germination rate, germination index, mean germination time) and seedling characteristics (seedling and root length, seedling and root dry weight, above ground dry weight/total dry weight ratio) were examined. According to obtained data; while small and medium seeds characteristics germination ratio and index, root length with above ground dry weight/total dry weight ratio (medium), root dry weight and above ground dry weight (small) characteristics; large seeds have superior in mean germination time with seedling lentgh. In terms of seed depth, When germination and seedling characteristics examined, 2 and $4 \mathrm{~cm}$ seed depth obtained values were maximum. As a result, germination and seedling characteristics of mung bean seeds with different grain sizes were affected by planting depths. In mung bean cultivation, it has been determined that if seeds of different sizes are sown at a depth of 2-4 cm and in terms of germination and seedling growth characteristics, superior plants can be obtained.
Anahtar Sözcükler: Çimlenme Ekim derinliği Fide parametreleri Maş fasulyesi Tane iriliği

Keywords: Germination Sowing depth Seedling parameters Mung bean Seed size

(C) OMU ANAJAS 2021 


\section{Giriş}

İnsan gıdası, hayvan beslenmesi ve yeşil gübre olarak kullanılan maş fasulyesi (Vigna radiata L.), bir sıcak mevsim baklagil türüdür (Karaman, 2019). Maş fasulyesinin taneleri \% 51 karbonhidrat, \% 26 protein, \% 10 nem, \% 4 mineral madde ve \% 3 vitamin içermekte olup, demir (100 g kuru tohum başına $6 \mathrm{mg}$ ) açısından zengindir. Maş fasulyesinin lizin (7 g / 16g N cinsinden), sistein (0.6 g / 16g), metheonin ( $1 \mathrm{~g} / 16 \mathrm{~g})$, treonin (3.5 g / 16g) ve triptofan $(0.4 \mathrm{~g} / 16 \mathrm{~g})$ amino asitleri bakımından öne çıkmakta ve tahıl tanelerinin tamamlayıcısıdır (Asaduzzaman ve ark., 2008). Bu nedenle maş fasulyesi yeterli miktarda içerdiği kaliteli proteinler sayesinde fakirin eti olarak kabul edilmektedir (Singh ve ark., 2018). Dahiya ve ark. (2015), maş fasulyesinin bin tane ağırlı̆̆ının 7.3-60.1 g arasında değiştiğini bildirmiş̧lerdir. Tane büyüklüğü genotip ve çevre şartlarına bağlı olarak değişim göstermekte olduğundan ekim yapılırken de tane büyüklüğü büyük önem arz etmektedir.

Azot fikse etme kabiliyeti, kısa vejetasyon süresi ve kuraklığa toleranslı olması sebebiyle maş fasulyesi orta bünyeli topraklara iyi adapte olabilmektedir (Shil ve Bandopadhyay, 2007). Dünya'da maş fasulyesinin yaklaşık 7.3 milyon ha alanda, 5.3 milyon ton üretimi vardır. Bu üretimin \% 30'unu Hindistan ve Myanmar oluşturmaktadır. Maş fasulyesi pazarı kullanıma göre; kuru tane (Güney Asya ve Kenya'da önemli), filiz (Doğu ve Güneydoğu Asya'da önemli), şeffaf erişte / nişasta (Doğu ve Güneydoğu Asya'da önemli) ve hamur/ezme (Doğu Asya'da önemli) olarak dört ana bölüme ayrılmıştır (Nair ve Schreinemachers, 2020). Türkiye'de ise maş fasulyesinin, Akdeniz ve Güneydoğu kuşaklarında bölgesel olarak yetiştiriciliği yapılmaktadır. Türkiye'deki çalışmalar incelendiğinde, maş fasulyesi tarımında çıkış oranları ve sürelerinde değişimler görülmektedir (Pekşen ve ark., 2015; Akgündüz, 2016; Karaman, 2019; Akbay ve ark., 2020). Çıkışlardaki bu değişimlerin çeşit özelliği, ekim derinliği ya da toprak sicaklığından kaynaklanabileceği düşünülmektedir.

Tohumların ekim derinliği, iyi bir ürün standardı ve daha yüksek verim elde etmeye katkıda bulunduğu için önemlidir (Siddig ve Abdellatif, 2015). Ayrıca ekim derinliği, tohumların çıkış süresi ve çıkış oranı üzerine direk etki etmektedir (Oda ve ark., 2009). Çünkü ekim derinliği, zaman içinde çimlenecek bitkinin tohum boyutuna yani, yedek gıda maddesine bağlıdır (Singh ve ark., 2010). Başarılı bir çimlenme, tohum boyutu (yedek gıda maddesi), koleoptil ve plumula uzunluğu ile ilişkilidir. Yüzlek ekim, toprak üst katmanındaki yetersiz toprak nemi nedeniyle düşük çimlenmeye neden olurken, derin ekim ise, bitkinin çimlenmesini ve verimi azaltabilmektedir (Aikins ve ark., 2008). Derin ekimde tohumlar çimlenirken kotiledonunu toprak yüzeyine çıkaramadıkları için toprak kaynaklı hastalıklar ve böceklerden zarar görürken, çok yüzlek ekilen tohumlar üst toprak yüzeyindeki nem eksikliği nedeniyle çimlenememekte veya alatava yakalanmaktadır. Ayrıca, abiyotik stres koşulları durumunda (kuraklık, sıcaklık gibi) ilkbahar ekimlerinin, derin yapıldığı durumlarda çıkışlar geciktiğinden verim düşmektedir (Özköse, 2017). Bu nedenle ekim derinliği, çimlenmenin başlamasından itibaren verim potansiyelini belirleyebilmektedir. Baklagil bitkilerinin verimliliğini optimum seviyeye getirmek için, ekim derinliği ve ekim geometrisi deneme kurmada önemli rol oynamaktadır (Baye ve ark., 2020). Genellikle tohum büyüklüğüne bağlı olarak ekim derinliği de değişim göstermektedir.

Bu çalışma; farklı tohum büyüklüğüne sahip maş fasulyelerinde en yüksek çıkış sağlayan ve en iyi fide gelişimi gösteren ekim derinliğinin belirlenmesini amaçlanmıştır.

\section{Materyal ve Yöntem}

Araştırma, Isparta Uygulamalı Bilimler Üniversitesi Ziraat Fakültesi uygulama alanında 2020 yılında açık alanda saksı denemesi şeklinde (16 Haziran - 24 Temmuz) yürütülmüştür. Çalışmada, büyük (Partow), orta (70 E 07) ve küçük (70 S 06) tohum iriliklerine sahip maş fasulyesi çeşit ve genotipleri kullanılmıştır. Büyük tohum iriliğine sahip Partow çeşidinin bin tane ağırlığı $58.7 \mathrm{~g}$, orta tohum iriliğine sahip 70 E 07 genotipinin bin tane ağırlığı $44.7 \mathrm{~g}$ ve küçük tohum iriliğine sahip 70 S 06 genotipinin bin tane ağırlığ 28.6 g olduğu bildirilmiştir (Karaman, 2019). Deneme alanında yapılan toprak örneklemelerine göre; deneme topraklarının killi-tınlı yapıda, hafif alkali ( $\mathrm{pH}$ değeri 7.7), hafif tuzlu, kireçli, organik madde içeriği bakımından fakir (\% 1.5), fosfor bakımından yeterli (23.5 $\mathrm{mg} / \mathrm{kg}$ ) seviyede, potasyum bakımından zengin $(772.2 \mathrm{mg} / \mathrm{kg})$ olduğu belirlenmiştir. Deneme aç1k alanda yapıldığından iklim koşulları büyük önem arz etmektedir. Deneme süresince sıcaklıklar $18.3-29.3^{\circ} \mathrm{C}$ arasında değişim göstermiştir (Şekil 1). 


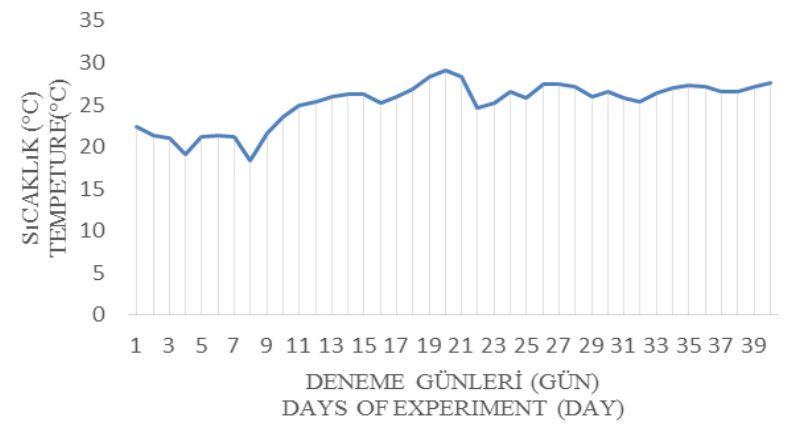

Şekil 1. Isparta ilinin deneme günlerine (16 Haziran- 24 Temmuz) ait ortalama sıcaklık değerleri

Figure 1. The mean temperature values experiment days of the province Isparta (June 16 - July 24)

Saksı toprağı için tarla toprağ 1 ve torf (3:1) karışımı ile harç yapılmış ve ağız çapı $33 \mathrm{~cm}$, dip (taban) çap $20 \mathrm{~cm}$ ve $28 \mathrm{~cm}$ boyundaki $13 \mathrm{~kg}$ 'lık plastik saksılara doldurulmuştur. Araştırma; Tesadüf Parselleri deneme deseninde Faktöriyel Düzenlemeye göre 3 tekerrürlü olarak kurulmuştur. Tohum büyüklerine (büyük, orta ve küçük) göre maş fasulyeleri 2, 4 ve $6 \mathrm{~cm}$ derinliğinde, her saksıda 25 adet tohum olacak şekilde ekim yapılmıştır. Ekimden hemen sonra saksılar sulanmış ve bundan sonra bitkilerin su ihtiyacına göre (iki günde bir) her saksıya eşit oranda su verilmiştir. Çıkışlar tamamlandıktan sonra saksılarda 10 bitki kalacak şekilde seyreltilmiştir. Saksılardaki kalan 10 bitki 40. gün sonunda kökleri ile sökülerek, bir elek üzerinde su ile yıkanıp temizlenmiş ve bazı çimlenme ile fide özellikleri incelenmiştir. Çıkış oranı; saksılara ekilen tohumlardan çıkış yapan bitkiler sayılmış ve \% olarak ifade edilmiştir. Çimlenme indeksi (GI)'nin hesaplanmasında; $(\mathrm{GI})=\sum(\mathrm{Gt} / \mathrm{Tt})$ formülü kullanılmış, burada Gt: ekimden sonraki t'inci günde çimlenen tohum sayısını, Tt: ekimden sonraki gün sayısını göstermektedir (Wang et al., 2004; Karaman ve Kaya, 2017). Ortalama çimlenme süresi ise; $(\mathrm{MGT})=\sum \mathrm{TiNi} / \sum \mathrm{Ni}$ formülü kullanılarak hesaplanmış, burada Ti: ekimden sonraki kaçıncı günde gözlem yapıldığını, Ni: gözlemin yapıldığı günde çimlenen tohum sayısını belirtmektedir (Ellis ve Robert, 1980; Karaman ve Kaya, 2017). Fide ve kök uzunluğu; cetvelle ölçülmüş ve cm olarak kaydedilmiştir. Kuru toprak üstü ve kök ağırlığı; bitkiler, kök ve toprak üstü kısımları kök boğazından kesilerek birbirinden ayrılmış ve etüvde sabit ağırlığa gelinceye kadar 700C sıcaklıkta tutularak, kuru ağırlıkları 0.01 g hassasiyetteki terazide tartılmış ve g olarak belirlenmiştir. Toprak üstü/kök kuru ağırlık oranı; kök ve toprak üstü kısımların kuru ağırlıkları belirlendikten sonra, toprak üstü kısmın kök kuru ağırlığına oranlanmasıyla bulunmuştur.

Araştırmada, elde edilen verilerin varyans ve korelasyon analizi TOTEMSTAT istatistik paket programı kullanılarak yapılmıştır. Ortalamalar arasındaki farklılıklar LSD testine göre 0.05 düzeyinde belirlenmiştir.

\section{Bulgular ve Tartışma}

\section{1. Çimlenme özellikleri}

Araştırmada, çimlenme özelliklerine ilişkin elde edilen verilerin istatistik analizlerine göre tüm çimlenme karakterlerinde genotip x ekim derinliği interaksiyonları 0.01 seviyesinde önemli bulunmuştur. Çimlenme oranı, genotiplere göre farklılık göstermiş, en yüksek çimlenme oranı 70 E 07 genotipinde (\% 89.33), en düşük ise Partow çeşidinde (\% 73.56) belirlenmiş olup, $70 \mathrm{E} 07$ ve $70 \mathrm{~S} 06$ genotipleri aynı istatistiki grupta yer almışlardır (Çizelge 1). Maş fasulyesi genotiplerinin en uygun ekim derinliği yönünden çimlenme oranı özelliğinde en yüksek değerler 4 cm'de belirlenmiştir. Tohumların kısa sürede yüksek çimlenme yüzdesini ifade eden çimlenme indeksi, çalışmada genotipler bakımından en yüksek 70 E 07 genotipinde belirlenmiş olup, $70 \mathrm{~S} 06$ genotipi ile aynı istatistiki grupta yer almıştır. Ekim derinliklerinin çimlenme indeksi ortalamaları $2.11-2.73$ arasında değişim göstermiş ve ekim derinliklerinin artmasıyla, çimlenme indeksi de azalmıştır. Maş fasulyesi genotipleri arasında en yüksek çimlenme indeksi, $2 \mathrm{~cm}$ ekim derinliğinde tespit edilmiştir.

Genotiplere göre, ortalama çimlenme süresi 6.29-7.55 gün arasında değişim göstermiştir. Genotipler arasında en kısa ortalama çimlenme süresi Partow çeşidinde tespit edilmiştir. En geç çimlenme $70 \mathrm{~S} 06$ genotipinde belirlenmiş ve $70 \mathrm{E} 07$ ve $70 \mathrm{~S} 06$ genotipleri arasında istatistiki olarak fark bulunamamıştır. Ekim derinliklerinin ortalama çimlenme süresi 6.76-7.71 gün arasında değişim göstermiş olup, en erken çimlenme $2 \mathrm{~cm}$ ekim derinliğinde belirlenmiştir. En kısa ortalama çimlenme süresine sahip olan $2 \mathrm{~cm}$ ekim derinliği ile $6 \mathrm{~cm}$ ekim derinliği istatistiki olarak aynı grupta yer almışlardır. Partow çeşidinde en kısa ortalama çimlenme süresi, $6 \mathrm{~cm}$ ekim derinliğinde belirlenmiş ancak, bunun sebebi $6 \mathrm{~cm}$ derinliğe ekilen maş fasulyelerinin çıkışı kısa zamanda tamamlaması ve 
çimlenme oranının düşük olmasından kaynaklanmaktadır. 70 E 07 genotipinin en erken çimlenme süresi ise $2 \mathrm{~cm}$ ekim derinliğinde belirlenirken, 2 ve $6 \mathrm{~cm}$ ekim derinlikleri arasında istatistiki olarak fark bulunamamıştır. $70 \mathrm{~S} 06$ genotipinin ise, ekim derinliklerin artmasıyla ortalama çimlenme süresi uzamıştır (Çizelge 1). Kara ve Akman (2007), buğday çeşitlerinin tohumlarını tane büyüklüğüne göre gruplandırmışlar ve farklı ekim derinliklerinde saksılara ektikleri çalışmada, ekim derinliğinin artması ile çimlenme oranında azalma gözlemlemişlerdir. Genellikle iri tohumların çimlenme oranlarının en yüksek olduğunu saptamışlar ve çalışma sonucunda ekim derinliği ve tane büyüklügünün bitkilerin performansını direk etkilediğini, ekim derinliğinin artmasının tane büyüklüğü ve çeşide bağlı olarak inceledikleri özellikler üzerinde olumsuz etkiye neden olduğunu belirlemişlerdir. Ekim derinliği üzerine yapılan çalışmalarda genel olarak ekim derinliğinin artması ile Kaya ve Şanlı (2008), nohut çeşitlerini optimum derinliğin dışındaki ekimlerin çıkış süresini geciktirdiğini; Tanveer et al. (2012), kavunda çimlenme oranı ve indeksinin azaldığını; Özaslan Parlak ve ark. (2013), çok yıllık çim tohumlarında çıkış oranlarında azaldığını; Özköse (2017), yem bezelyesi hatlarını çıkış süresinin arttığını ve çıkış oranın azaldığını; Baye et al. (2020), baklada ekim derinliğinin artması ile çıkış süresinin uzadığını (7 günden 12 güne) ve çimlenme oranının ise azaldığını (\% 90.1'den \% 65.1'e) bildirmişlerdir. Araştırmacılar çalışmanın sonucunda ekim derinliğinin fide çıkışı, gelişimi ve ürün verimi üzerine etkili olduğunu ve üniform tohum derinliğinin yüksek verim elde etmek için önemli bir faktör olduğunu bildirmişlerdir.

Ekim derinliği tekdüze bir çıkış olması, büyüme, verim ve elde edilen ürünün kalitesi üzerinde önemli etkiye sahiptir. Ekimin yüzlek yapılması toprağın üst katmanındaki nem içeriğinin yetersiz olması durumunda çimlenme oranını düşürebilmekte ya da çimlenmenin başlamasının ardından toprağın kuruması ile tohum canlılığını kaybedebilmektedir. Ekimin derin yapılması ise, çimlenme süresini uzatırken, bunun yanında avantajları da bulunmaktadır. Derin ekim yapılması, herbisit uygulaması yapılan alanlarda çıkışın geciktirilip yabancı otlarla rekabeti önlemesi ve ayrıca yüzlek ekimde diğer bir sorun olan kuş zararını da ortadan kaldırmaktadır. Tohum büyüklüğü, genotip, toprak strüktürü ve sıcaklığı ekim derinliği üzerinde etkili olan önemli faktörlerdir (Özköse, 2017). Ayrıca toprak sıcaklığı da çıkış için önemli bir faktördür. Karaman (2019), maş fasulyesi genotiplerini Isparta koşullarında iki yetiştirme sezonunda ekmiş (2017-2018) ve ilk yıl ekim yapılan Nisan ayında ortalama sıcaklıklar $10.6^{\circ} \mathrm{C}$ olması sebebiyle çıkışların ikinci yıla göre $\left(14.2^{\circ} \mathrm{C}\right)$ genel olarak daha geç olduğunu ve çıkış süresinin genotiplere göre değişim gösterdiğini ifade etmiştir. Özköse (2017), toprak sıcaklığının düşük olduğu zamanlarda yüzlek ekim yapılmasının daha avantajlı olacağını bildirmiştir. Yapılan araştırmaların sonuçları, çalışmayı destekler niteliktedir.

Çizelge 1. Tane iriliği farklı maş fasulyesi genotiplerinde ekim derinliğinin çimlenme özelliklerine ait ortalamalar

Table 1. The means of germination properties of sowing depth in mung bean genotypes with different seed size

\begin{tabular}{|c|c|c|c|c|}
\hline \multirow{3}{*}{$\begin{array}{l}\text { Çeşit-Genotipler } \\
\text { Variety-Genotypes }\end{array}$} & \multicolumn{4}{|c|}{$\begin{array}{l}\text { Ekim Derinlikleri }(\mathrm{cm}) \\
\text { Sowing Depth }(\mathrm{cm})\end{array}$} \\
\hline & 2 & 4 & 6 & Ortalama /Mean \\
\hline & \multicolumn{4}{|c|}{ Çimlenme Oranı (\%)/Germination Ratio (\%) } \\
\hline Partow & $81.33 \mathrm{a}$ & $86.00 \mathrm{a}$ & $53.33 \mathrm{~b}$ & $73.56 \mathrm{~B}^{*}$ \\
\hline 70 Е 07 & $92.00 \mathrm{a}$ & 93.33 a & $82.67 \mathrm{~b}$ & $89.33 \mathrm{~A}$ \\
\hline 70 S 06 & $84.00 \mathrm{~b}$ & $96.00 \mathrm{a}$ & $82.67 \mathrm{~b}$ & $87.56 \mathrm{~A}$ \\
\hline Ort. /Mean & $85.78 \mathrm{~B}$ & $91.78 \mathrm{~A}$ & $72.89 \mathrm{C}$ & \\
\hline \multirow[t]{2}{*}{$\mathrm{Cv}$} & 8.44 & & & \\
\hline & \multicolumn{4}{|c|}{ Çimlenme İndeksi/Germination Index } \\
\hline Partow & $2.52 \mathrm{a}$ & $2.44 \mathrm{a}$ & $1.59 \mathrm{~b}$ & $2.18 \mathrm{~B}$ \\
\hline 70 E 07 & $2.90 \mathrm{a}$ & $2.68 \mathrm{~b}$ & $2.49 \mathrm{~b}$ & $2.69 \mathrm{~A}$ \\
\hline $70 \mathrm{~S} 06$ & $2.77 \mathrm{a}$ & $2.70 \mathrm{a}$ & $2.24 \mathrm{~b}$ & $2.57 \mathrm{~A}$ \\
\hline Ort. /Mean & $2.73 \mathrm{~A}$ & $2.61 \mathrm{~B}$ & $2.11 \mathrm{C}$ & \\
\hline \multirow[t]{2}{*}{$\mathrm{Cv}$} & 8.63 & & & \\
\hline & \multicolumn{4}{|c|}{$\begin{array}{c}\text { Ortalama Çimlenme Süresi (gün)/ } \\
\text { Mean Germination Time (day) }\end{array}$} \\
\hline Partow & $6.44 \mathrm{~b}$ & $7.68 \mathrm{a}$ & $4.75 \mathrm{c}$ & $6.29 \mathrm{~B}$ \\
\hline 70 Е 07 & $7.20 \mathrm{~b}$ & $7.77 \mathrm{a}$ & $7.36 \mathrm{~b}$ & $7.44 \mathrm{~A}$ \\
\hline $70 \mathrm{~S} 06$ & $6.64 \mathrm{c}$ & $7.68 \mathrm{~b}$ & $8.32 \mathrm{a}$ & $7.55 \mathrm{~A}$ \\
\hline Ort. /Mean & $6.76 \mathrm{~B}$ & $7.71 \mathrm{~A}$ & $6.81 \mathrm{~B}$ & \\
\hline $\mathrm{Cv}$ & 11.84 & & & \\
\hline
\end{tabular}

*Aynı sütunda farklı harflerle gösterilen ortalamalar arasındaki fark önemlidir $(\mathrm{P}<0.05)$. 


\subsection{Fide ve kök özellikleri}

Çalışmada, farklı ekim derinliklerinde ekilen, farklı tohum iriliklerine sahip maş fasulyesi çeşit ve genotiplerinde, fide ile kök uzunluğu, toprak üstü ile kök kuru ağırllğı ve toprak üstü/toplam kuru ağırlığı özelliklerine ilişkin elde edilen verilerin istatistik analizlerine göre tüm karakterlerde genotip $\mathrm{x}$ ekim derinliği interaksiyonları 0.01 seviyesinde önemli bulunmuştur.

Araştırmada, ekim derinliklerinin artmasına bağlı olarak fide uzunluğu da azalmıştır. En yüksek fide uzunluğu $15.52 \mathrm{~cm}$ ile Partow çeşidinde elde edilmiş, $70 \mathrm{~S} 06$ ve 70 E 07 genotipleri arasında istatistiki olarak fark bulunamamıştır. Genotipler içerisinde en yüksek fide uzunluğu $2 \mathrm{~cm}$ ekim derinliğinde (sırasıyla 16.55, 13.50 ve $14.86 \mathrm{~cm}$ ) belirlenmiştir. En düşük fide uzunluğu ise, yine her üç genotipte de $6 \mathrm{~cm}$ ekim derinliğinde tespit edilmiştir.

Çizelge 2'de görüldüğü gibi, ekim derinliğinin ana etkisi incelendiğinde en uzun kök uzunluğu 70 E 07 genotipinde $(38.60 \mathrm{~cm})$ belirlenmiş, en kısa kök uzunluğu ise $70 \mathrm{~S} 06$ genotipinde $(36.55 \mathrm{~cm})$ tespit edilmiştir. $70 \mathrm{~S}$ 06 genotipi ile Partow çeşidi istatistiki olarak aynı grupta yer almıştır. Ekim derinliğine göre, en uzun kök uzunluğu $4 \mathrm{~cm}$ ekim derinliğinde tespit edilirken, 2 ve $6 \mathrm{~cm}$ ekim derinlikleri arasında istatistiki olarak fark bulunamamıştır. 70 E 07 genotipi ve Partow çeşidinde en uzun kök uzunluğu $4 \mathrm{~cm}$ ekim derinliğinde belirlenirken (sırasıyla 37.65 ve $41.95 \mathrm{~cm}$ ), $4 \mathrm{~cm}$ ekim derinliği ile diğer ekim derinlikleri arasında bir fark ortaya çıkmamıştır. $70 \mathrm{~S} 06$ genotipinde ise, en uzun kök uzunluğu diğer genotip ve çeşidin aksine $6 \mathrm{~cm}$ ekim derinliğinde belirlenmiş olup, 2 ve $4 \mathrm{~cm}$ ekim derinliği ile $6 \mathrm{~cm}$ ekim derinliği aynı istatistiki grupta yer almıştır.

Çeşit ve genotiplerin oluşturdukları toprak üstü kuru ağırlık miktarları önemli farklılıklar göstermiş, ekim derinliklerinin ortalaması olarak en yüksek toprak üstü kuru ağırlık $70 \mathrm{~S} 06$ genotipinde $(9.62 \mathrm{~g})$ belirlenmiş, bunu azalan sırayla Partow çeşidi (6.49 g) ve 70 E 07 genotipi $(5.72 \mathrm{~g})$ izlemiştir. Ekim derinliklerine göre toprak üstü kuru ağıllığı en yüksek $6 \mathrm{~cm}$ ekim derinliğinde, en düşük ise $4 \mathrm{~cm}$ ekim derinliğinde tespit edilmiştir. Çeşit ve genotiplere göre en yüksek toprak üstü kuru ağırlık, Partow çeşidi ve $70 \mathrm{~S} 06$ genotipinde $6 \mathrm{~cm}$ ekim derinliğinde tespit edilirken, 70 E 07 genotipinde ise, $2 \mathrm{~cm}$ ekim derinliğinde belirlenmiştir. Çeşit ve genotiplere göre en küçük toprak üstü kuru ağırlığı Partow çeşidinde $2 \mathrm{~cm}$ ekiminde, $70 \mathrm{E} 07$ ve $70 \mathrm{~S} 06$ genotiplerinde ise $4 \mathrm{~cm}$ ekim derinliğinde tespit edilmiştir (Çizelge 2).

Çeşit ve genotiplerin oluşturdukları kök kuru ağırlık miktarları önemli farklılıklar göstermiş, çeşit ve genotiplerin ortalaması olarak en yüksek toprak üstü kuru ağırlık $70 \mathrm{~S} 06$ genotipinde belirlenmiş $(9.62 \mathrm{~g})$, bunu azalan sırayla 70 E 07 (3.84 g) ve Partow (2.43 g) çeşidi izlemiştir. Ekim derinliğinin ana etkisi incelendiğinde en yüksek kök kuru ağırlık $4 \mathrm{~cm}$ ekim derinliğinde belirlenirken, $4 \mathrm{~cm}$ ekim derinliği ile $2 \mathrm{~cm}$ ekim derinliği istatistiki olarak aynı grupta yer almıştır. Maş fasulyelerinin çeşit ve genotiplerin kök kuru ağırlık bakımından ekim derinliklerine tepkileri farklı olmuş, en yüksek kök kuru ağırlığı sırasıyla 70 E 07 ve 70 S 06 genotiplerinde 2 cm'de (sırasıyla 6.48 ve $3.99 \mathrm{~g}$ ), Partow çeşidinde ise, $6 \mathrm{~cm}$ (2.99 g) ekim derinliğinde belirlenmiştir (Çizelge 2).

70 E 07 ve $70 \mathrm{~S} 06$ genotiplere göre en yüksek toprak üstü/toplam kuru ağırlık oran1 $70 \mathrm{E} 07$ genotipinde belirlenmiş (\% 0.40), bunu azalan sırayla 70 S 06 genotipi (\% 0.38) ve Partow çeşidi (\% 0.27) izlemiştir. Ekim derinliklerine göre en yüksek toprak üstü/toplam kuru ağırlık oranı $4 \mathrm{~cm}$ ekim derinliğinde tespit edilmiştir. Maş fasulyesi çeşit ve genotiplerinin, en yüksek toprak üstü/toplam kuru ağırlık oranı her üçünde de $4 \mathrm{~cm}$ ekim derinliğinde (sırasıyla \% $0.30, \% 0.42$ ve \%0.42) belirlenmiştir (Çizelge 2).

Silvertown (1981)'a göre, tohum büyüklüğü ile üretkenlik arasında önemli korelasyonlar bulunmaktadır. Yaptı̆̆ araştırmada küçük tohumların hayatta kalmak için daha fazla tohum ürettiğini ve yaşam sürelerinin iri tohumlulara göre kısa olduğunu bildirmiştir. Foster (1986), tohum büyüklüğünün, tohumlukların yayılma mesafesinin, fide gelişiminin ve hatta hayatta kalmasının belirlenmesinde önemli bir faktör olduğunu ifade etmiştir. Tohum ağırlığındaki farklılığın depo maddelerinin miktarındaki farklılıktan kaynaklandığını, büyük tohumların fidelerinin boyu küçük tohumların fidelerinden daha uzun olduğunu ve büyük tohumları daha derine ekildiğini saptamışlardır. Ayrıca araştırıcılar, tohum büyüklüğünün kotiledon alanı ve ağırlığı, yaprak alanı, kök ağırlık ve toplam fide kuru ağırlığı ile pozitif olarak ilişkili olduğunu belirlemişlerdir. Büyük tohumlardan elde edilen fidelerin, besin içeriğinin küçük tohumlulara göre daha fazla olduğunu ve kotiledonların erken döneminde fidelerin büyümesine katkısı, fotosentetik kapasiteden çok depolama kapasitelerine bağlı olduğunu saptamışlardır. Murali (1997), fide yapısı küçük tohumlarda içerdiği bileşenlerin az olması sebebiyle daha zayıf yapıda, büyük tohumlar ise, daha iyi durumda ve daha fazla hayatta kalma şansına sahip olduğunu bildirmiştir. Edwards ve Hartwig (1971), soya küçük ve orta büyüklükteki tohumlarının, çimlenmenin gerçekleştiği tüm nem seviyelerinde büyük tohumlardan daha hızlı çimlenmiş ve daha büyük kök gelişimi sağladığını bildirmişlerdir. Aikins ve Afuakwa (2008), börülcede ekim derinliğinin ortalama fide çıkışını, bitki boyu, gövde çevresi, yaprak sayısı ve kuru madde verimini etkilediğini rapor etmişlerdir. 
Fatima ve ark. (2009), maş fasulyesi çeşidinin 15, 30, 45 ve 60 gün boyunca incelemişler ve en yüksek bitki boyutunun $4 \mathrm{~cm}$ derinliğe ekilen ve büyük boyuttaki materyallerde saptamışlardır. Thiyam ve ark. (2017), bezelye tohumlarını yüzlek ektiklerinde büyük tohumlar, maximum sayıda fide (sürgün+kök) oluşturmuş ve bu fidelerin boylarının daha yüksek olduğunu bildirmişlerdir. Yapılan çalışmaların sonuçları araştırmamızı destekler niteliktedir.

Çizelge 2. Tane iriliği farklı maş fasulyesi genotiplerinde ekim derinliğinin fide uzunluğu, kök uzunluğu, topraküstü kuru ağırlı̆̆ı, kök kuru ağırlığı ve toprak üstü/toplam kuru ağırlı̆̆ına ait ortalamalar

Table 2. The means of seedling length, root length, dry weight above ground, root dry weight and above ground / total dry weight of 109owing depth in mung bean genotypes with different seed size

\begin{tabular}{|c|c|c|c|c|}
\hline \multirow{3}{*}{$\begin{array}{l}\text { Çeşit-Genotipler } \\
\text { Variety-Genotypes }\end{array}$} & \multicolumn{3}{|c|}{$\begin{array}{l}\text { Ekim Derinlikleri }(\mathrm{cm}) \\
\text { Sowing Depth }(\mathrm{cm}) \\
\end{array}$} & \multirow[b]{2}{*}{ Ortalama/ Mean } \\
\hline & 2 & 4 & 6 & \\
\hline & \multicolumn{4}{|c|}{ Fide Uzunluğu $(\mathrm{cm}) /$ Seedling Length $(\mathrm{cm})$} \\
\hline Partow & $16.55 \mathrm{a}$ & $15.10 \mathrm{~b}$ & $14.92 \mathrm{~b}$ & $15.52 \mathrm{~A}^{*}$ \\
\hline 70 E 07 & 13.50 a & $12.25 \mathrm{~b}$ & $12.11 \mathrm{~b}$ & $12.62 \mathrm{~B}$ \\
\hline $70 \mathrm{~S} 06$ & $14.86 \mathrm{a}$ & $13.75 \mathrm{a}$ & $9.95 \mathrm{~b}$ & $12.85 \mathrm{~B}$ \\
\hline Ort. /Mean & $14.97 \mathrm{~A}$ & $13.70 \mathrm{~B}$ & $12.33 \mathrm{C}$ & \\
\hline \multirow[t]{2}{*}{$\mathrm{Cv}$} & 3.3 & & & \\
\hline & \multicolumn{3}{|c|}{ Kök Uzunluğu $(\mathrm{cm}) /$ Root Length $(\mathrm{cm})$} & \\
\hline Partow & $36.24 \mathrm{a}$ & $37.65 \mathrm{a}$ & $35.85 \mathrm{a}$ & $36.58 \mathrm{~B}$ \\
\hline 70 Е 07 & $36.83 \mathrm{~b}$ & $41.95 \mathrm{a}$ & $37.03 \mathrm{~b}$ & $38.60 \mathrm{~A}$ \\
\hline $70 \mathrm{~S} 06$ & 36.85 a & 35.35 a & $37.45 \mathrm{a}$ & $36.55 \mathrm{~B}$ \\
\hline Ort. /Mean & $36.64 \mathrm{~B}$ & $38.32 \mathrm{~A}$ & $36.78 \mathrm{~B}$ & \\
\hline \multirow[t]{2}{*}{$\mathrm{Cv}$} & 2.92 & & & \\
\hline & \multicolumn{4}{|c|}{ Toprak Üstü Kuru Ağırlık (g)/ Above Ground Dry Weight (g) } \\
\hline Partow & $5.43 \mathrm{c}$ & $6.03 \mathrm{~b}$ & $8.01 \mathrm{a}$ & $6.49 \mathrm{~B}$ \\
\hline 70 E 07 & $6.44 \mathrm{a}$ & $4.79 \mathrm{c}$ & $5.92 \mathrm{~b}$ & $5.72 \mathrm{C}$ \\
\hline $70 \mathrm{~S} 06$ & $9.74 \mathrm{~b}$ & $8.93 \mathrm{c}$ & $10.19 \mathrm{a}$ & $9.62 \mathrm{~A}$ \\
\hline Ort. /Mean & $7.20 \mathrm{~B}$ & $6.58 \mathrm{C}$ & $8.04 \mathrm{~A}$ & \\
\hline \multirow[t]{2}{*}{$\mathrm{Cv}$} & 11.49 & & & \\
\hline & \multicolumn{4}{|c|}{ Kök Kuru Ağırlık (g)/Root Dry Weight $(\mathrm{g})$} \\
\hline Partow & $1.89 \mathrm{c}$ & $2.49 \mathrm{~b}$ & $2.90 \mathrm{a}$ & $2.43 \mathrm{C}$ \\
\hline 70 E 07 & $3.99 \mathrm{a}$ & $3.58 \mathrm{~b}$ & 3.96 a & $3.84 \mathrm{~B}$ \\
\hline $70 \mathrm{~S} 06$ & $6.48 \mathrm{a}$ & $6.42 \mathrm{a}$ & $5.14 \mathrm{~b}$ & $6.01 \mathrm{~A}$ \\
\hline Ort. /Mean & $4.12 \mathrm{AB}$ & $4.16 \mathrm{~A}$ & $4.00 \mathrm{~B}$ & \\
\hline $\mathrm{Cv}$ & 5.82 & & & \\
\hline \multicolumn{5}{|c|}{$\begin{array}{c}\text { Toprak üstü kuru ağırlık/Toplam Kuru Ağırlık oranı (\%)/Above Ground Dry Weight/Total } \\
\text { Dry Weight Ratio (\%) }\end{array}$} \\
\hline Partow & $0.26 \mathrm{~b}$ & $0.30 \mathrm{a}$ & $0.27 \mathrm{~b}$ & $0.27 \mathrm{C}$ \\
\hline 70 E 07 & $0.38 \mathrm{~b}$ & $0.42 \mathrm{a}$ & $0.40 \mathrm{ab}$ & $0.40 \mathrm{~A}$ \\
\hline $70 \mathrm{~S} 06$ & $0.39 \mathrm{~b}$ & $0.42 \mathrm{a}$ & $0.33 \mathrm{c}$ & $0.38 \mathrm{~B}$ \\
\hline Ort. /Mean & $0.34 \mathrm{~B}$ & $0.38 \mathrm{~A}$ & $0.33 \mathrm{~B}$ & \\
\hline $\mathrm{Cv}$ & 9.84 & & & \\
\hline
\end{tabular}

* Aynı sütunda farklı harflerle gösterilen ortalamalar arasındaki fark önemlidir $(\mathrm{P}<0.05)$.

\subsection{Incelenen özellikler arası ilişsiler}

Çalışmada çimlenme özellikleri arasında olumlu ve önemli ilişkiler bulunmaktadır. Ortalama çimlenme süresinin artması ile çimlenme oranı ( $\mathrm{r}=0.630)$ ve çimlenme indeksi $(\mathrm{r}=0.567)$ değerleri artmıştır. Çimlenme özelliklerinin değerlerinin artması ile fide uzunluğunun azaldığı (negatif korelasyon) belirlenmiştir. Çimlenme özelliklerinden OÇS özelliği ile fide uzunluğu arasında olumsuz ve önemli; toprak üstü kuru ağırlık /toplam kuru ağırlık arasında önemli ve olumlu ilişkiler olduğu belirlenmiştir (Çizelge 3). 
Çalışmada ortalama çimlenme süresinin artması ile fide uzunluğu değerlerinde azalmalar tespit edilmiştir. Fide uzunluğunun artması ile kök uzunluğunun azaldığı ve bu iki özellik arasında önemsiz ve negatif korelasyon olduğu gözlemlenmiştir. Murali (1997), fide yapısı küçük tohumlarda içerdiği bileşenlerin az olması sebebiyle daha zayıf yapıda, büyük tohumlar ise, daha iyi durumda ve daha fazla hayatta kalma şansına sahip olduğunu bildirmiştir. Ayrıca, araştırıcı yaptığı çalışmada tohum büyüklüğü ile çiçeklenme ve meyve verme süresi arasında önemli ve negatif bir ilişki (negatif korelasyon), çimlenme ve yaşama gücü arasında ise önemli ve olumlu bir ilişki olduğunu bildirmiştir. Toprak üstü kuru ağıllık ile kök uzunluğu arasında önemli ve negatif korelasyon saptanmıştır. Bu durumun da fide uzunluğu ile kök uzunluğu arasında negatif ilişki (negatif korelasyon) bulunmasından kaynaklandığ1 düşünülmektedir. Toprak üstü kuru ağırlığı ile de kök kuru ağırlığ1 arasında önemli ve negatif korelasyon gözlenmiş̧ir. Fide uzunluğunun artması ile toprak üstü kuru ağırlığı artmış, kök uzunluğu azalmış ve kök kuru ağırlığı da azalmıştır. Toprak üstü kuru ağırlık ile kök kuru ağırlığı arasındaki ilişki Atılgan ve Tolay (2008) ve Eren ve Demirel (2020)'nin yürüttüğü çalışmalar ile benzerlik göstermektedir. Çimlenme oranı, çimlenme indeksi, ortalama çimlenme süresi ve kök kuru ağırlığı artması ile toprak üstü kuru ağırlık /toplam kuru ağırlık oranı arttığı, fide uzunluğunun artması ile azaldığı görülmüștür. Korelasyon analizi sonucunda incelenen özelliklere göre, çeşit ve genotiplerin ekim derinliğinin artması ile fide uzunluğu azalış göstermiş olup, bu da bitkinin optimum derinlikten daha derine ekildiğinde fidenin gelişiminin azaldığını göstermiştir.

Çizelge 3. İncelenen Özelliklere Ait Korelasyon Katsayıları

Table 3. Correlation Coefficients of Belong to Examined Properties

\begin{tabular}{cccccccc}
\hline Özellikler & ÇO & Çİ & OÇS & FU & KU & TÜKA & KKA \\
\hline Çİ & $0.713^{* *}$ & & & & & & \\
OÇS & $0.630^{* *}$ & $0.567^{* *}$ & & & & & \\
FU & $-0.180^{\text {öd }}$ & $-0.023^{\text {öd }}$ & $-0.595^{* *}$ & & & & \\
KU & $0.280^{\text {odd }}$ & $0.229^{\text {öd }}$ & $0.340^{\text {öd }}$ & $-0.366^{\text {öd }}$ & & & \\
TÜKA & $-0.173^{\text {öd }}$ & $-0.177^{\text {öd }}$ & $0.006^{\text {öd }}$ & $0.256^{\text {od }}$ & $-0.412^{*}$ & & \\
KKA & $0.244^{\text {öd }}$ & $0.356^{\text {od }}$ & $0.310^{\text {öd }}$ & $-0.379^{\text {odd }}$ & $-0.141^{\text {od }}$ & $-0.749^{* *}$ & \\
HO & $0.513^{* *}$ & $0.629^{* *}$ & $0.520^{* *}$ & $-0.484^{*}$ & $0.290^{\text {öd }}$ & $0.069^{\text {öd }}$ & $0.682^{* *}$ \\
\hline
\end{tabular}

* \% 5 düzeyinde önemli, ** \% 1 düzeyinde önemli, öd önemli değil, ÇO: çimlenme oranı, Çİ: çimlenme indeksi, OÇS: ortalama çimlenme süresi, FU: fide boyu, KU: kök uzunluğu, TÜKA: toprak üstü kuru ağırlık, KKA: kök kuru ağırlık, HO: toprak üstü kuru ağırlık /toplam kuru ağırlık oranı

\section{Sonuç}

Ülkemizde tüketimi yeni popülarite kazanan maş fasulyesi genellikle ithal olarak pazara sürülmektedir. Halbuki, ülkemiz için alternatif bir baklagil türü olarak maş fasulyesinin ülke çiftçisine tanıtılması ve yetiştiriciliğin yaygınlaştırılması büyük önem arz etmektedir. Bu sayede her yıl yapılan maş fasulyesi ithalat miktarı da azalacaktır. Yetiştirme teknikleri içerisinde ekim normunun bilinmesi üretimin artması için oldukça önemlidir. Bu çalışma ile de farklı boyuttaki maş fasulyesi çeşit ve genotiplerinin hangi derinliklerde ekilmesi gerektiği ve bu derinliklerin çıkış ile fide gelişimi üzerine etkileri incelenmiştir.

Çalışmada farklı tane büyüklüğüne sahip maş fasulyesi genotiplerinin çimlenme ve fide özellikleri ekim derinliklerinden etkilenmiştir. Özellikle çimlenme özellikleri üzerine $6 \mathrm{~cm}$ 'ye yapılan ekimlerin çeşit ve genotipler için olumsuz etki etmiştir. Derine ekim $(6 \mathrm{~cm})$ ile özellikle iri taneli Partow çeşidinde çimlenme oranlarını önemli seviyede azalttığg görülmüş̧ür. Bu durumun aksine maş fasulyesi tohumlarını $4 \mathrm{~cm}$ derinliğe ekilmesi ile önemli performans kriterleri olan çimlenme özellikleri, kök uzunluğu, kök kuru ağırlığı ve toprak üstü kuru ağırlık/ kök kuru ağırlığı oranı üzerine belirgin şekilde olumlu etkileri gözlemlenmiştir. Çalışmada ekim derinliği ve çeşit ile genotiplerin fide uzunluğu üzerinde oldukça fazla etkili olmuştur. Fide uzunluğu artan ekim derinlikleri ile çeşit ve genotiplerin olumsuz etkilendiği ve $2 \mathrm{~cm}$ ekilen tohumların farklı boyutta genotipler de olsa en iyi sonuçlar verdiği belirlenmiştir. Bunun sebebi olarakda, toprak yüzeyine yakın olan tohumların çimlenmesini hızlıca tamamlaması ve fide gelişimini artırması olarak düşünülmektedir. Bu nedenle maş fasulyesinin $2-4 \mathrm{~cm}$ derinliğe ekilebileceği ve bunun sonucunda çimlenme ile fide gelişim özellikleri yönünden üstün bitkilerin elde edilebileceği saptanmıştır. 


\section{Kaynaklar}

Aikins, S. H. M., Afuakwa, J. J., 2008. Growth and dry matter yield responses of cowpea to different sowing depths. ARPN Journal of Agricultural and Biological Science, 3(5-6): 50-54.

Akbay, F., Uslu, Ö.S., Erol, A., 2020. The effect of different planting times on the agronomic characteristics and forage quality of mung bean (Vigna radiata (L.) Wilczek). Turkish Journal of Agriculture-Food Science and Technology,8(5): 1160-1165. doi: https://doi.org/10.24925/turjaf.v8i5.1160-1165.3335.

Akgündüz, M., 2016. Maş fasulyesi (Vigna radiata (L.) Wilczek) genotiplerinin kuraklık hassasiyetlerinin belirlenmesi. Yüksek Lisans Tezi. Ondokuz Mayıs Üniversitesi Fen Bilimleri Enstitüsü, 96s, Samsun.

Asaduzzaman, M., Karim, M.F., Ullah, J., Hasanuzzaman, M., 2008. Response of mungbean (Vigna radiata L.) to nitrogen and irrigation management. American-Eurasian Journal of Scientific Research, 3(1):40-43.

Atılgan, N. G., Tolay, İ., 2008. Beş tritikale çeşidinde çinkonun bazı fide özelliklerine etkisi. Akdeniz Üniversitesi Ziraat Fakültesi Dergisi, 21(1): 65-74.

Barış, E., Demirel, F., 2020. Fide gelişim dönemindeki bazı buğday genotiplerinde özellikler arası korelasyon analizi. Journal of Agriculture, 3(1): 28-32.

Baye, E., Ebirahim, Z., Kasahun, N., Wasyihun, N., Siyum, K., Yachiso, D., Msanya, B.M., 2020. Effects of planting depth on germination and growth of faba bean (Vicia faba L.) at fitche, oromia national regional state, Central Ethiopia. American Journal of Agriculture and Forestry, 8(3): 58-63. doi: 10.11648/j.ajaf.20200803.11.

Dahiya, P.K., Linnemann, A.R., Van Boekel, M.A.J.S., Khetarpaul, N., Grewal, R.B., Nout, M.J.R., 2015. Mung bean: Technological and nutritional potential. Critical reviews in food science and nutrition, 55(5): 670688. doi: 10.1080/10408398.2012.671202.

Edwards Jr, C.J., Hartwig, E.E., 1971. Effect of seed size upon rate of germination in soybeans. Agronomy Journal, 63(3): 429-450. doi: https://doi.org/10.2134/agronj1971.00021962006300030024x

Ellis, R.H., Roberts, E.H., 1980. Towards a Rational Basis for Testing Seed Quality. In Seed Production (Ed: P.D. Hebblethwaite), 605-635, Butterworths, London.

Fatima, K., Biswas, P. K., Ali, H., Rahman, J., 2010. Emergence and seedling attributes of mungbean (Vigna radiata (L.) Wilczek) as influenced by sowing depth and seed size. International Journal of Agriculture, Environment and Biotechnology, 3(4), 343-348.

Foster, S.A., 1986. On the adaptive value of large seeds for tropical moist forest trees: a review and synthesis. The Botanical Review, 52(3): 260-299.

Kara, B., Akman, Z., 2007. Farklı tane iriliği ve ekim derinliklerinin buğday (Triticum aestivum L.)'ın kök ve toprak üstü organlarının ilk gelişmesine etkisi. Akdeniz Üniversitesi Ziraat Fakültesi Dergisi, 20(2): 193-202.

Karaman, R., 2019. Maş fasulyesi (Vigna radiata Wilczek) genotiplerinin/yerel populasyonlarının 1sparta koşullarında fenolojik, morfolojik, agronomik ve bazı teknolojik özellikler yönünden karakterizasyonu. Doktora Tezi. Isparta Uygulamalı Bilimler Üniversitesi Lisansüstü Eğitim Enstitüsü, 226s, Isparta.

Karaman, R., Kaya, M., 2017. Mercimeğe (Lens esculanta Moench) uygulanan farklı klor tuzu ve dozlarının kimi ilk gelişme özelliklerine etkisi. Journal of Agricultural Sciences, 23: 10-21.

Kaya, M., Şanlı, A., 2008. Ekim derinliğinin nohut (Cicer arietinum L.) çeşitlerinde kök ve toprak üstü organlarının ilk gelişmesine etkisi. Süleyman Demirel Üniversitesi Fen Bilimleri Enstitüsü Dergisi, 12(2): 115-122.

Murali, K.S., 1997. Patterns of seed size, germination and seed viability of tropical tree species in southern India. Biotropica, 29(3): 271-279.

Nair, R., Schreinemachers, P., 2020. Global status and economic 1mportance of mungbean. In The Mungbean Genome (pp. 1-8). Springer, Cham.

Oda, M. C., Sediyama, T., Barros H.B., 2009. Manejo da cultura. In: Sediyama T (ed.) Tecnologia de produção e usos da soja. Editora Mecenas, Londrina, p.93-99.

Özaslan Parlak, A., Demiray, H. C., Hakyemez, B. H., Parlak M., Gökkuş, A., 2013.Toprak bünyesi ve ekim derinliğinin çok yıllık çimin (Lolium perenne) sürme özelliklerine etkisi. Türkiye X. Tarla Bitkileri Kongresi, Cilt 3, 568-573, 13-15 Eylül, Konya.

Özköse, A., 2017. Farklı ekim derinliklerinin yem bezelyesinin verim ve bazı verim özellikleri üzerine etkileri. Sakarya University Journal of Science, 21(6), 1188-1200. doi: 10.16984/saufenbilder.306457.

Pekşen, E., Toker, C., Ceylan, F. Ö., Aziz, T., Farooq, M., 2015. Determination of promising high yielded mungbean (Vigna radiata (L.) Wilczek) genotypes under middle black sea region of Turkey. Anadolu Tarım Bilimleri Dergisi, 30 (2): 169-175. doi: 10.7161/anajas.2015.30.2.169-175.

Shil, S., Bandopadhyay, P.K., 2007. Retaining seed vigor and viability of mungbean by dry dressing treatments. Journal of Food Legumes, 20:75-173.

Siddig, A.M.A., Abdellatif, Y.I., 2015. Effect of seed size and sowing depth on germination and some growth parameters of faba bean (Vicia faba L.). Agricultural and Biological Sciences Journal,1(1): 1-5. 
Silvertown, J. W., 1981. Seed size, life span, and germination date as coadapted features of plant life history. The American Naturalist, 118(6):860-864.

Singh, A. K., Bharat, R. C., Chandra, N., Dimree, S., 2010. Effect of seed size and seeding depth on fava bean (Vicia fava L.) productivity. Environment and Ecology, 28 (3A): 1722- 1727.

Singh, R., Heusden, A.W.V., Kumar, R., Visser, R.G.F., 2018. Genetic variation and correlation studies between micronutrient ( $\mathrm{Fe}$ and $\mathrm{Zn}$ ), protein content and yield attributing traits in mungbean (Vigna radiata $\mathrm{L}$.). Legume Research, 41:167-74. doi: 10.18805/lr.v0i0.7843

Tanveer, A., Salman Arshad, M., Ayub, M., Mansoor Javaid, M., Yaseen, M., 2012. Effect of temperature, light, salinity, drought stress and seeding depth on germination of Cucumis melo var. agrestis. Pakistan Journal of Weed Science Research, 18(4): 445-459.

Thiyam, R., Yadav, B., Rai, P. K., 2017. Effect of seed size and sowing depth on seedling emergence and seed yield of pea (Pisum sativum). Journal of Pharmacognosy and Phytochemistry, 6(4), 1003-1005.

Wang, Y. R., Yu, L., Nan, Z. B., Liu, Y. L., 2004. Vigor tests used to rank seed lot quality and predict field emergence in four forage species. Crop Science, 44 (2): 535-541. 